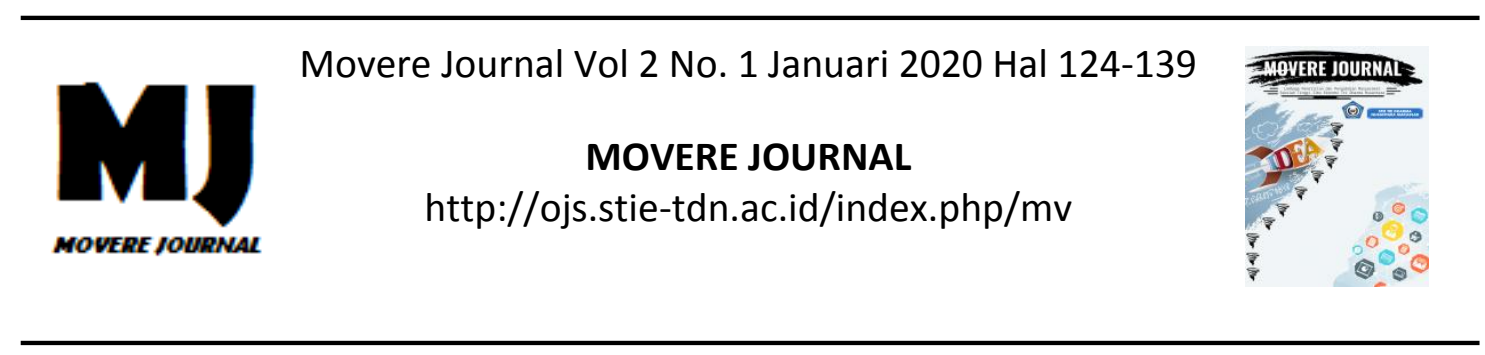

\title{
FAKTOR- FAKTOR YANG MEMPENGARUHI KEPUTUSAN PEMBELIAN DI WARKOP 89 MAMUJU
}

\author{
Yusran Fajar Panca Putra ${ }^{(1)}$, Muhlis ${ }^{(2)}$ \\ Sekolah Tinggi Ilmu Ekonomi Muhammadiyah Mamuju
}

\begin{abstract}
Abstrak : Penelitian ini bertujuan untuk mengetahui variabel kualitas produk, kualitas pelayanan dan lingkungan secara parsial dan simultan, serta untuk mengetahui faktor mana yang paling dominan pengaruhnya terhadap keputusan pembelian di Warkop 89 Mamuju. Hasil penelitian ini menunjukkan bahwa faktor kualitas produk, kualitas pelayanan dan lingkungan secara simultan berpengaruh terhadap keputusan pembelian di Warkop 89 Mamuju. Hal ini ditunjukkan oleh nilai signifikansi kurang dari 0,05 yaitu 0,001 . Secara parsial yang berpengaruh positif dan simultan adalah semua variabel terikat yaitu kualitas produk, kualitas pelayanan dan lingkungan. Variabel yang paling dominan pengaruhnya adalah faktor lingkungan dengan nilai signifkansi 0,001 .
\end{abstract}

Keyword : kualitas produk, kualitas pelayanan, lingkungan, keputusan pembelian, warung kopi

\section{PENDAHULUAN}

Di Indonesia, khususnya di kabupaten Mamuju, baik diperkotaan dan pelosok daerah atau diluar kota Mamuju, coffe shop atau biasa disebut warung kopi telah menjamur dan menjadi style atau gaya hidup baru bagi masyarakat. Definisi coffee shop menurut Wiktionary (2010) bisa diartikan sebuah cafe kecil atau restoran kecil yang biasanya menjual kopi dan terkadang minuman nonalkohol, makanan sederhana atau snacks, dengan fasilitas yang menunjang di tempat tersebut. Senada dengan Wiktionary, pengertian coffee shop atau Warung kopi sendiri dalam kamus besar Bahasa Indonesia karya Poerwadarminta adalah sebuah tempat yang menjual kopi dan jenis minuman lain, serta makanan-makanan kecil dengan berbagai kisaran harga (Anik, 2012).

Di Mamuju sendiri banyak sekali Warung kopi atau coffee shop tersedia dari yang berskala lokal dan nasional dengan kelebihannya masingmasing, seperti Cafe Copy Paste, Teras Mamuju. Ngalo Rock Cafe, Project Cafe, Bangi Cafe, eat n' joy Resto dan Cafe, Warkop Dg. Sija' dan lainnya. Masyarakat diberi kebebasan untuk memilih sesuai keinginannya yang tentunya dipengaruhi oleh faktor-faktor tertentu.

Masing-masing coffee shop yang berada di Mamuju memiliki identitas berbeda dan saling menawarkan ciri khasnya untuk menarik perhatian konsumen. Terlepas dari kopi itu sendiri, coffee shop juga

(C) 2020 STIE TDN. All rights reserved 
mengalami pergeseran fungsi. Tempat ini tidak hanya digunakan sebagai tempat untuk minum kopi tetapi telah menjadi ruang publik alternatif yang memiliki beragam fungsi. Berbagai kegiatan seperti pertemuan-pertemuan keluarga, pertemuan bisnis, pertemuan politis, termasuk acara-acara sosialbudaya lainnya, kerap diadakan di tempat ini. Maka tidak heran jika banyak kedai kopi yang didesain dengan interior yang nyaman dan gaya yang unik agar konsumen tertarik untuk mengunjungi. Terlebih lagi coffee shop juga menyajikan menu hidangan selain kopi sehingga membuat konsumen menjadi betah untuk berlama-lama.

Salah satu cafe berbasis coffee shop yang berada di Mamuju adalah Warkop 89 yang terletak di Jl. Andi Makkasau No - Kelurahan Karema Kabupaten Mamuju. Yang memiliki lingkungan yang sangat strategis karena lingkungan bisnis dan berdekatan dengan pasar baru. Produk yang ditawarkan hampir sama dengan warkop atau cafe lain yaitu kopi dengan variasi produk, seperti Kopi Hitam, Kopi Susu, Cappucinno, dll. Yang menjadi ciri khas kopi warkop ini adalah kopi yang ditaburi bagian atas atau topping serbuk espresso, cream, dan lain-lain yang di kenal dengan nama kopi thailand (thai coffee). Kopi ini divariasikan menjadi beberapa produk baik diseduh air panas maupun air dingin. Tujuan kedai ini dibuat dimana untuk memenuhi kebutuhan masyarakat mamuju akan tempat "nongkrong" yang dianggap baik untuk kalangan mahasiswa, pengusaha, pejabat pemerintahan di Mamuju terlebih posisi yang dibawa Warkop 89 ke benak konsumen adalah kedai yang murah dan nyaman. Sejak Warkop 89 berdiri hingga sekarang dalam memiliki pendapatan yang terus meningkat.
Dengan perkebangan usaha semakin maju kini Warkop 89 telah memiliki tempat usaha lantai 2, yang dapat digunakan sebagai tempat meeting/rapat baik komunitas atau rapat lainnya, serta terdapat tempat mushallah. Kini warkop 89 telah menata ruang lebih elegan dan nyaman, serta tersedia wifi gratis sehingga konsumen betah dan berlama-lama di dalam warkop tersebut.

Dengan berdasar pada yang penulis uraikan di atas, maka penulis akan membahas tentang : "FaktorFaktor Yang Mempengaruhi Keputusan Pembelian di Warkop 89 Mamuju"

Penelitian ini bertujuan untuk mengetahui apakah faktor kualitas produk, kualitas pelayanan dan lingkungan secara bersama-sama dan parsial berpengaruh terhadap keputusan pembelian di Warkop 89 Mamuju, dan untuk mengetahui faktor manakah yang paling dominan pengaruhnya terhadap keputusan pembelian di Warkop 89 Mamuju.

\section{TELAAH LITERATUR DAN PENGEMBANGAN HIPOTESIS}

\section{Pengertian Pemasaran}

Konsep pemasaran meliputi keseluruhan sistem yang berhubungan dengan kegiatan usaha, yang bertujuan merencanakan, menentukan harga, hingga mendistribusikan dan mempromosikan barang atau jasa dalam rangka memenuhi kebutuhan pelanggan. Menurut Kotler (2011), strategi pemasaran yang dikenal sebagai bauran pemasaran adalah seperangkat alat pemasaran yang digunakan perusahaan untuk terus menerus mencapai tujuan pemasarannya di pasar sasaran. Jangkauan pemasaran sangat luas, berbagai tahap kegiatan harus dilalui barang dan jasa sebelum akhirnya 
dapat digunakan oleh konsumen, sehingga ruang lingkup kegiatan yang luas disederhanakan menjadi empat kebijakan pemasaran yang lazim disebut bauran pemasaran (marketing mix). Keputusan bauran pemasaran harus diambil untuk mempengaruhi saluran perdagangan dan juga konsumen akhir. McCarthy dalam Kotler (2011), mengklasifikasikan bauran pemasaran menjadi empat kelompok luas yang disebut $4 \mathrm{P}$, yaitu : produk (product), harga (price), tempat (place), dan promosi (promotion).

1. Product Mix (Bauran Produk)

Konsep produk menegaskan bahwa konsumen akan menyukai produk-produk yang menawarkan ciri paling bermutu, berkinerja atau inovatif. Variabel-variabel produk dalam bauran pemasaran yaitu : keragaman produk, kualitas, desain, ciri, nama merek, kemasan, ukuran, pelayanan, garansi dan imbalan. Dalam mengembangkan produk yang dapat berupa barang, jasa, maupun layanan, perusahaan harus menetapkan manfaatmanfaat apa yang harus diberikan oleh produk tersebut dan mengomunikasikannya kepada konsumen.

2. Price Mix (Bauran Harga)

Variabel-variabel pemasaran harga diantaranya daftar harga, rabat atau diskon, potongan harga khusus, periode pembayaran, syarat kredit. Harga merupakan jumlah uang yang menyatakan nilai tukar suatu satuan barang atau jasa. Menurut Aaker (2016) menyatakan harga adalah sejumlah nilai yang ditukarkan konsumen dengan manfaat untuk memiliki atau menggunakan produk atau jasa yang nilainya ditetapkan oleh pembeli dan penjual melalui tawar menawar, atau ditetapkan oleh penjual untuk satu harga yang sama terhadap semua pembeli.

3. Place Mix (Bauran Tempat)

Keputusan membeli suatu produk juga dapat dipengaruhi oleh kemudahan memperoleh dan sarana tempat pembeliannya. Variabelvariabel pemasaran tempat yaitu saluran pemasaran, cakupan pasar, pengelompokkan, lingkungan, persediaan, transportasi. Keputusan tentang tempat dimana konsumen akan membeli suatu produk dipengaruhi atribut yang mencolok dari tempat tersebut, seperti harga, iklan dan promosi, personal penjualan, pelayanan yang diberikan, atribut fisik, pelanggan toko, atmosfer toko dan pelayanan setelah transaksi. Menurut Anik (2012) saluran distribusi ini membentuk tingkatan saluran untuk menentukan panjangnya saluran distribusi. Saluran tingkat nol, tidak mempunyai perantara, jadi langsung dari produsen ke konsumen. Saluran tingkat 1 mempunyai satu tingkat pedagang perantara, seperti pengecer. Saluran tingkat 2 mempunyai dua tingkat pedagang perantara, seperti grosir lalu ke pengecer. Dan yang terakhir saluran tingkat 3 yang mempunyai tiga tingkat pedagang pengecer, seperti pemborong yang ada diantara grosir dan pengecer. Semakin banyak jumlah tingkat saluran pemasaran, semakin sulit untuk melaksanakan saluran pengendalian dan memperoleh informasi yang akurat mengenai konsumen tingkat akhir.

4. Promotion Mix (Bauran Promosi)

Bauran promosi mengacu pada strategi yang memadukan produk, harga, promosi, dan distribusi. Variabel-variabel dalam bauran pemasaran yaitu promosi penjualan, periklanan, tenaga penjualan, kehumasan, pemasaran langsung. Bauran promosi lebih memfokuskan bagaimana mengomunikasikan suatu produk kepada masyarakat sehingga nantinya akan dikenal dan pada akhirnya dikonsumsi. 


\section{Konsep Kualitas Produk}

Produk yang berkualitas tentu memiliki nilai lebih bagi pelanggan. Kualitas merupakan hal penting dan paling mendasar dari kepuasan konsumen dan kesuksesan dalam bersaing (Anik, 2012). Kiat yang dilakukan pelaku usaha dalam bersaing salah satunya yaitu dengan menjaga kualitas produknya. Menurut Kotler (2012), kualitas produk adalah keseluruhan ciri serta sifat dari suatu produk atau jasa yang berpengaruh pada kemampuan untuk memuaskan kebutuhan yang dinyatakan atau tersirat.

\section{Konsep Kualitas Pelayanan}

Kualitas pelayanan dapat didefinisikan sebagai ukuran seberapa baik tingkat layanan yang diberikan mampu sesuai dengan ekspektasi pelanggan. Kualitas pelayanan bukanlah dilihat dari sudut pandang pihak penyelenggara atau penyedia layanan, melainkan berdasarkan persepsi masyarakat (pelanggan) penerima layanan. Pelangganlah yang mengonsumsi dan merasakan pelayanan yang diberikan, sehingga merekalah yang seharusnya menilai dan menentukan kualitas pelayanan (Tjiptono, 2014).

Buttle (2015) menyatakan kualitas layanan yang baik akan memberikan manfaat yang baik bagi pemenuhan kepuasan pelanggan sehingga akan menciptakan nilai lebih bagi pelanggan. Pelanggan membeli harapan untuk mendapatkan manfaat. Layanan yang berkualitas menyeimbangkan antara manfaat dan pengorbanan dari persamaan nilai yang dapat ditingkatkan pada sisi pelanggan. Penelitian Hosmer menunjukkan pula korelasi positif antara kualitas pelayanan terhadap nilai pelanggan. Terdapat pula pengaruh yang signifikan antara kualitas layanan terhadap nilai pelanggan seperti yang ditunjukkan pada penelitian yang dilakukan Swasta (2012).

\section{Konsep Pengaruh Lingkungan}

Pengaruh lingkungan memiliki peran yang cukup besar terhadap perilaku konsumen. Informasi yang lengkap mengenai faktor lingkungan yang mempengaruhi perilaku konsumen memberikan masukan yang snagat berarti terhadap strategi pemasaran suatu perusahaan. Menurut Engel et Al (2010) faktor lingkungan terdiri dari:

1. Budaya

Budaya merupakan penentu keinginan dan perilaku yang paling mendasar. Konsumen mendapatkan kumpulan nilai, persepsi dan preferensi, dan perilaku dari keluarganya serta lembaga-lembaga penting lainnya. Setiap budaya terdiri dari sub-budaya yang lebih kecil yang memberikan lebih banyak ciri-ciri dan sosialisasi khusus bagi anggotaanggotanya. Sub-budaya yang membentuk segmen pasar penting dan pemasar sering merancang produk dan program pemasaran yang disesuaikan dengan kebutuhan mereka.

2. Kelas Sosial

Kelas sosial adalah pembagian didalam masyarakat yang terdiri atas individu dengan nilai, minat, dan perillaku yang sama atau kelompok yang relatif homogen didalam suatu masyarakat lama yang tersusun secara hierarki. Kelas sosial yang berbeda cenderung memunculkan perilaku konsumsi yang berbeda. Dalam pemasaran, sistem status merupakan faktor yang sangat menarik untik diketahui karena mereka dapat mengusahakan pengaruh yang besar pada apa yang akan dibeli dan dikonsumsi oleh seseorang.

3. Pengaruh Pribadi

Pengaruh pribadi berkaitan dengan cara-cara dimana kepercayaan, sikap dan perilaku konsumen 
dipengaruhi ketika orang lain digunakan sebagai kelompok acuan. Menurut Listyari (2016) kelompok acuan (reference group) adalah orang atau kelompok yang mempengaruhi secara bermakna perilaku individu. Kelompok acuan memberikan standard dan nilai yang dapat menjadi perspektif penentu yang penting dalam pengaruh pribadi adalah keterlibatan. Keterlibatan produk yang tinggi dan pengaruh sosial berhubungan dalam dua cara. Pertama, keterlibatan meningkat bila pilihan yang dibuatnya mempengaruhi status sosial seseorang dan penerimanya. Kedua, keterlibatan yang tinggi juga mencetuskan pencarian informasi dari orang yang dapat dipercaya.

4. Keluarga

Keluarga adalah kelompok yang terdiri dari dua atau lebih orang yang berhubungan melalui darah, perkawinan, atau adopsi dan tinggal bersama. Keluarga inti adalah kelompok langsung yang terdiri dari ayah, ibu dan anak yang tinggal bersama. Keluarga besar mencakup keluarga inti yang ditambah kerabat lain seperti kakek, nenek, paman, bibi dan sepupu. Dinyatakan juga studi tentang keluarga dan hubungan mereka dengan pembelian dan konsumsi penting karena dua alasan, yaitu banyak produk akan dibeli oleh konsumen ganda yang bertindak sebagai unit keluarga, dan keputusan pembelian individu yang bersangkutan mungkin dipengaruhi oleh anggota lain dalam keluarganya.

\section{Situasi}

Perbedaan individu merupakan faktor internal yang menggerakkan dan mempengaruhi perilaku. Terdapat lima determinan yang penting yang dapat membedakan konsumen adalah sumber daya konsumen, motivasi, keterlibatan, pengetahuan, sikap, kepribadian, gaya hidup dan demografi.

6. Pekerjaan dan lingkungan ekonomi \begin{tabular}{crr}
\multicolumn{2}{c}{ Pekerjaan dan lingkungan } \\
ekonomi & seseorang & dapat
\end{tabular} mempengaruhi pola konsumsinya. Cotohnya, direktur perusahaan akan membeli pakaian yang mahal, perjalanan dengan pesawat udara, keanggotaan di klub khusus, dan membeli mobil mewah. Selain itu, biasanya pemilihan produk juga dilakukan berdasarkan oleh keadaan ekonomi seseorang seperti besaran penghasilan yang dimiliki, jumlah tabungan, utang dan sikap terhadap belanja atau menabung.

7. Kepribadian, Gaya Hidup, dan Demografi

Kepribadian merupakan karakteristik psikologis yang berbeda dari setiap orang yang memandang responnya terhadap lingkungan yang relatif konsisten. Gaya hidup adalah pola hidup di dunia yang diekspresikan oleh kegiatan, minat dan pendapat seseorang. Gaya hidup mencerminkan sesuatu dibalik kelas sosial seseorang serta menggambarkan cara interaksi seseorang dengan lingkungannya. Demografi adalah mendeskripsikan pangsa pasar konsumen dalam istilah seperti usia, pendapatan, dan pendidikan.

pengaruh lingkungan yang terdiri dari pengaruh orang terdekat (selain keluarga) dan pengaruh rekan kerja atau teman sekomunitas. Pengaruh dari orang terdekat serta rekan kerja dapat membuat konsumen pada akhirnya melakukan pembelian karena adanya pengaruh yang cukup kuat. Pengaruh lingkungan ini juga dapat digunakan sebagai media promosi kepada konsumen dengan menggunakan metode word of mouth, sehingga konsumen lebih banyak mendapatkan informasi mengenai Warkop 89 langsung dari rekan kerja maupun orang terdekat mereka yang pernah melakukan pembelian di Warkop 89. 


\section{Konsep Keputusan Pembelian}

Kotler dan Keller (2016) mengemukakan bahwa keputusan pembelian adalah proses dimana konsumen secara aktual melakukan pembelian produk. Saat memutuskan untuk membeli sesuatu menurut Kotler (2011) konsumen melalui lima tahap proses pembelian konsumen, yaitu pengenalan masalah, pencarian informasi, evaluasi alternatif, keputusan pembelian, dan perilaku pasca pembelian.

Informasi dari beberapa sumber akan menjadi pertimbangan untuk mengambil keputusan. Banyak hal yang dipertimbangkan oleh konsumen dalam menilai suatu produk. Manfaat yang diharapkan menjadi acuan dalam menentukan pilihan termasuk kepercayaan merek dan biaya atau berbagai risiko sepeti: risiko waktu, tenaga, biaya, risiko psikologis dan sosial akan turut dipertimbangkan. Konsumen menggunakkan informasi merek yang bersaing dan mengolahnya untuk membuat penilaian akhir. Pada tahap ini terjadi evaluasi alternatif yang dilakukan konsumen. Menuju tahap selanjutnya yakni antara evaluasi alternatif dan keputusan pembelian konsumen akan melewati tahap yang dijelaskan oleh gambar berikut.

Gambar1: Model Perilaku Pengambilan Keputusan Konsumen dan Faktor-Faktor yang Mempengaruhinya

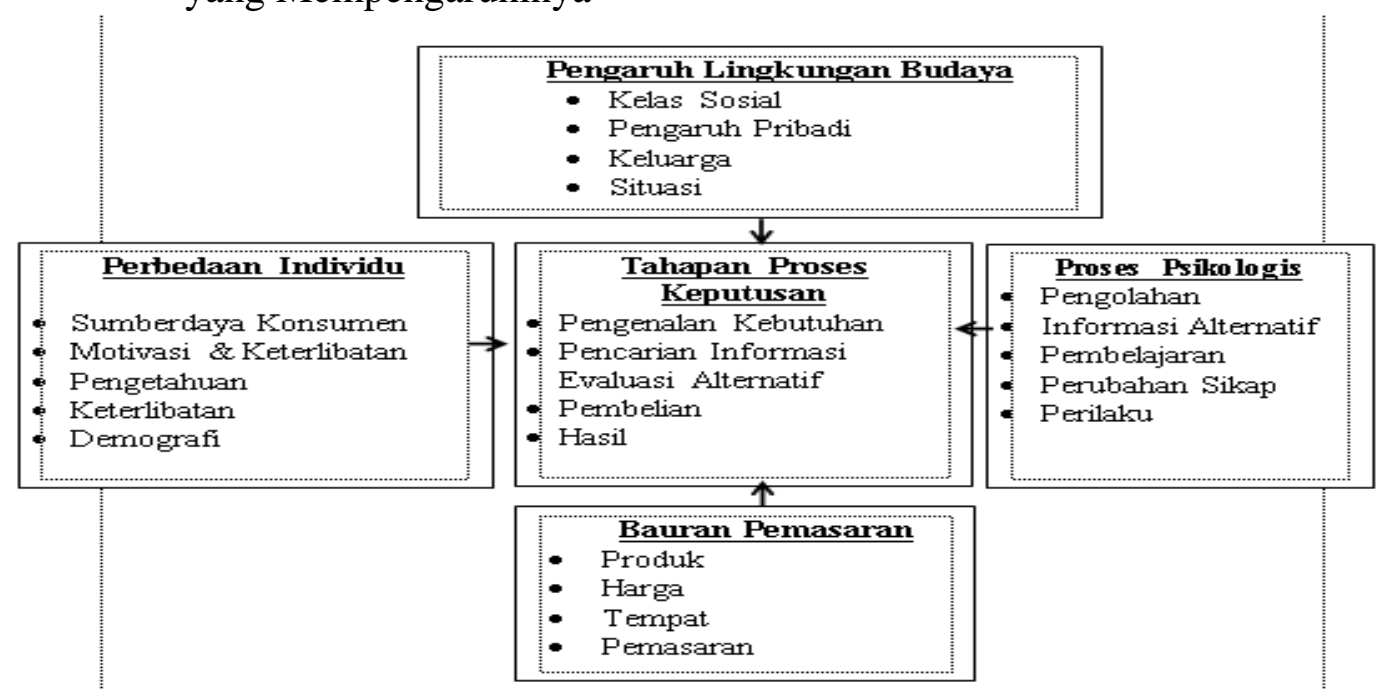

Sumber: Engel et al 2010

Menurut Engel, Blackwell dan Miniard (2010) terdapat empat prinsip signifikan yang mendasari perilaku konsumen, yaitu:

1. Konsumen adalah raja

Produk dan jasa yang akan diterima atau ditolak oleh konsumen berdasarkan sejauh mana keduanya dipandang relevan dengan kebutuhan dan gaya hidup konsumen tersebut.

Motivasi dan peilaku konsumen dapat dimengerti melalui penelitian Terdapat banyak pengaruh yang mendasari baik itu internal maupun eksternal yang mempengaruhi perilaku konsumen. Namun, motivasi dan perilaku dapat dimengerti walaupun secara tidak sempurna melalui peneitian. Prediksi yang sempurna tidak pernah akan mungkin dilakukan, tetapi usaha yang didesain dan digunakan dengan tepat menurunkan resiko kegagalan pemasaran secara berarti.

2. Perilaku konsumen dapat
dipengaruhi
Pemasar yang terampil dapat
mempengaruhi motivasi maupun


perilaku bila produk atau jasa yang ditawarkan didesain untuk memenuhi kebutuhan pelanggan. Pengeluaran promosi yang tinggi tidak mencegah kegagalan dari sebagian besar produk baru yang diperkenalkan di pasar setiap tahunnya.

3. Pengaruh konsumen sah secara sosial

Kebutuhan konsumen adalah riil dan ada manfaat yang tidak dapat disangkal dari produk atau jasa yang menawarkan kegunaan murni. Kunci bagi legitimasi sosial adalah jaminan bahwa konsumen tetap memiliki kebebasan lengkap dan tanpa rintangan sepanjang proses. Pengaruh yang tidak tepat menimbulkan pelanggaran etika yang serius sehingga mengharuskan pembuatan undang-undang dan bentuk lain kegiatan perlindungan.

4. Proses Keputusan Pembelian

Keputusan konsumen dalam mengkonsumsi barang dan jasa ditentukan oleh perilaku konsumen yang bersangkutan. Untuk meraih keberhasilan seorang produsen harus harus melihat faktor yang mempengaruhi pembelian, seperti siapa yang membuat keputusan pembelian, jenis-jenis keputusn pembelian dan langkah-langkah dalam proses pembelian. Phillip Kotler (2012) membedakan lima peran yang dimainkan konsumen dalam keputusan pembelian :

a.Pencetus, adalah seseorang yang pertama kali mengusulkan gagasan untuk membeli suatu produk atau jasa.

b.Pemberi pengaruh, adalah seseorang yang pendangan atau sarannya mempengaruhi keputusan pembelian.

c. Pengambil keputusan, adalah seseorang yang mengambil keputusan untuk setiap komponen keputusan pembelian.

d.Pembeli, adalah orang yang melakukan pembelian sesungguhnya.

e.Pemakai, adalah seseorang yang mengonsumsi atau menggunakan produk yang bersangkutan.

Proses keputusan pembelian meliputi beberapa tahapan. Menurut Engel et al (2010) terdapat lima tahapan kepuutsan pembelian yang dilkukan oleh konsumen, yaitu pengenalan kebutuhan, pencarian informasi, evaluasi alternatif, pembelian dan perilaku pasca pembelian.

Gambar 2:Tahap-Tahap Proses Pengambilan Keputusan

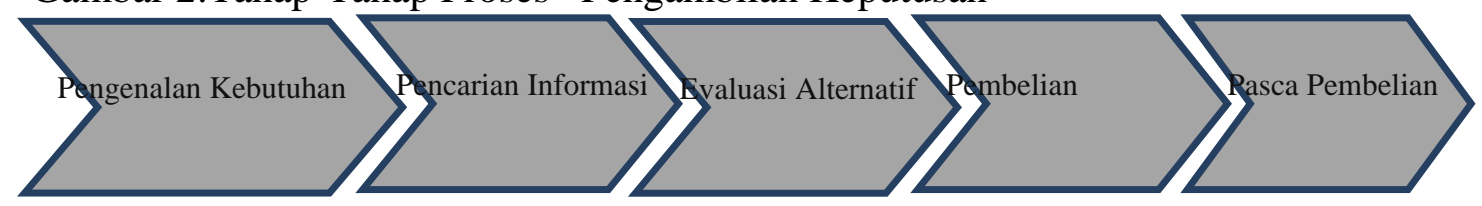

Sumber: Kotler \& Keller (2012)

1) Pengenalan Kebutuhan

Proses pembelian dimulai saat pembeli mengenali suatu kebutuhan. Kebutuhan tersebut dapat dicetuskan oleh stimulan baik internal maupun eksternal. Menutrut Phillip Kotler (2012) stimulan internal seseorang meliputi rasa lapar, haus, saat mencapai titik tertentu dapat menjadi sebuah dorongan. Sedangkan kebutuhan karena rangsangan eksternal seperti seseorang melewati sebuah toko kue dan melihat roti segar yang menstimulasi rasa laparnya. Seorang produsen perlu mengidentifikasi stimulan yang paling sering membangkitkan minat akan suatu kategori produk. 
Produsen kemudian dapat mengembangkan strategi pemasaran yang memicu minat konsumen.

Engel, Blackwell dan Miniard (2010) menjelaskan bahwa pengenalan kebutuhan merupakan suatu persepsi atas perbedaan antara keadaan yang diinginkan dengan situasi aktual yang memadai untuk menggugah dan mengaktifkan proses kebutuhan. Bila ketidaksesuaian yang ada melebihi tingkat ambang tertentu, maka kebutuhan akan dikenali. Namun ketidaksesuaian itu berada di bawah tingkat ambang, maka pengenalan kebutuhan yang berpusat pada tingkat ketidaksesuaian sulit untuk dikenali.

2) Pencarian Informasi

Konsumen yang tergugah akan kebutuhannya akan terdorong untuk mencari informasi yang lebih banyak. Phillip Kotler (2011) membaginya ke dalam dua tingkat yaitu situs pencarian yang lebih ringan dinamakan perhatian yang menguat. Pada tingkat ini seseorang hanya menjadi lebih peka terhadap informasi tentang produk. Sumber informasi konsumen digolongkan menjadi empat golongan, yaitu :

a) Sumber pribadi, termasuk keluarga, teman, tetangga, kenalan

b) Sumber komersial, termasuk iklan, wiraniaga, penyalur, kemasan

c) Sumber publik, termasuk media massa

d) Sumber pengalaman, termasuk penanganan, pengkajian dan pemakaian produk

Jumlah dan pengaruh relatif sumber-sumber informasi itu berbeda-beda secara umum konsumen mendapatkan sebagian besar, informasi tentang suatu produk dari sumber komersial, yaitu sumber yang didominasi oleh pemasar. Namun informasi yang paling efektif berasal dari sumber pribadi. Informasi komersial biasanya menjalankan fungsi pemberi informasi, dan sumber pribadi menjalankan fungsi legitimasi atau evaluasi.

3) Evaluasi Alternatif

Engel, Blackwell dan Miniard (2010) mendefinisikan evaluasi alternatif sebagai proses dimana suatu alternatif pilihan dievaluasi dan dipilih untuk memenuhi kebutuhan konsumen. Terdapat beberapa proses evaluasi keputusan, yaitu :

a) Menentukan kriteria evaluasi yang akan digunakan untuk menilai kinerja dari alternatif

b) Memutuskan alternatif pilihan

c) Menilai kinerja alternatif yang dipertimbangkan

d) Menerapkan kaidah keputusan untuk membuat pilihan akhir.

Phillip Kotler (2011) menyatakan bahwa tidak ada proses evaluasi tunggal sederhana yang digunakan oleh semua konsumen atau oleh satu konsumen dalam situasi pembelian. Beberapa konsep dasar untuk memahami proses evaluasi konsumen, yaitu konsumen berusaha untuk memenuhi kebutuhan, konsumen mencari manfaat tertentu dari solusi produk dan terakhir, konsumen memandang masing-masing produk sebagai kesimpulan atribut dengan kemampuan yang berbedabeda dalam memberikan manfaat yang digunakan untuk memuaskan kebutuhan tersebut.

4) Pembelian

Phillip Kotler (2011) menyatakan bahwa terdapat dua faktor yang dapat mempengaruhi niat pembelian dan keputusan pembelian. Faktor pertama adalah pendirian orang lain. Sejauh mana pendirian orang lain mengurangi alternatif yang disukai seseorang tergantung pada intensitas 
pendirian negatif orang lain terhadap alternatif yang disukai konsumen dan motivasi konsumen untuk memenuhi keinginan orang lain. Semakin gencar sikap negatif orang lain dan semakin dekat orang lain tersebut dengan konsumen, semakin besar konsumen akan menyesuaikan niat pembeliannya. Sedangkan faktor yang kedua adalah situasi tidak terantisipasi yang dapat muncul dan mengubah niat pembelian.

Keputusan konsumen untuk memodifikasi, menunda atau menghindari suatu keputusan pembelian sangat dipengaruhi oleh resiko yang dirasakan. Besarnya resiko yang dirasakan berbedabeda menurut besarnya uang yang dipertaruhkan, besarnya ketidakpastian atribut dan besarnya kepercayaan diri konsumen. Konsumen mengembangkan rutinitas tertentu untuk mengurangi resiko, seperti penghindaran keputusan, pengumpulan keputusan informasi dari teman-teman dan preferensi atas merek dalam negeri dan garansi.

5) Perilaku Pasca Pembelian

Setelah membeli produk konsumen akan melakukan evaluasi, apakah dia mengalami level kepuasan atau ketidakpuasan tertentu. Apabila hasil evaluasi pasca pembelian konsumen dianggap dapat memenuhi kebutuhan dan keinginannya, maka hal ini akan berpengaruh positif terhadap pembelian selanjutnya. Sehingga diharapkan kepuasan konsumen yang berfungsi untuk mendapatkan loyalitas terhadap produk dapat dicapai dan konsumen akan melakukan kegiatan pembelian selanjutnya. Hal ini menyebabkan penurunan loyalitas konsumen terhadap produk yang mengakibatkan keuhan konsumen, komunikasi lisan yang negatif, dan upaya menuntut ganti rugi melalui jalur hukum.

\section{Hipotesis}

Berdasarkan uraian teori diatas maka peneliti mengasumsikan hipotesis sebagai berikut :

$\mathrm{H}_{1}$ : faktor kualitas produk, kualitas pelayanan dan lingkungan bersama-sama berpengaruh terhadap keputusan pembelian di Warkop 89 Mamuju

$\mathrm{H}_{2}$ : faktor kualitas produk berpengaruh terhadap keputusan pembelian di Warkop 89 Mamuju

$\mathrm{H}_{3}$ : faktor kualitas pelayanan berpengaruh terhadap keputusan pembelian di Warkop 89 Mamuju

$\mathrm{H}_{4}$ : faktor lingkungan berpengaruh terhadap keputusan pembelian di Warkop 89 Mamuju

\section{METODE PENELITIAN}

Jenis penelitian ini dilakukan peneliti adalah penelitian penjelasan (explanatory research) dengan pendekatan kualitatif. Sampel dalam penelitian ini sebanyak 100 orang. Teknik pengambilan sampel dalam penelitian ini menggunakan teknik Simple Random Sampling, yaitu pengambilan sampel dengan cara acak sederhana melalui daftar bilangan random, sehingga setiap elemen populasi mempunyai kesempatan yang sama untuk terpilih menjadi anggota sampel yang akan diteliti.

Teknik Analisis data yang digunakan adalah :

1. Uji Validitas

Uji validitas digunakan untuk mengukur sah atau valid tidaknya suatu kuesioner. Dengan jumlah sampel (n) adalah dan tingkat 
signifikansi 0,05 maka $r_{\text {tabel }}$ pada penelitian ini adalah : r $(0,05 ; 80$ 3)=77 Bila : $r_{\text {hitung }}>r_{\text {tabel }}$, berarti pernyataan tersebut dinyatakan valid. $r_{\text {hitung }} \leq r_{t_{\text {abel }}}$, berarti pernyataan tersebut dinyatakan tidak valid (Sugiyono,2014).

\section{Uji Realibilitas}

Uji realibilitas digunakan untuk mengukur sejauh mana suatu alat ukur dapat dipercaya atau dapat diandalkan. Hal ini berarti menujukkan sejauh mana alat pengukur dikatakan konsisten, jika dilakukan pengukuran dua kali atau lebih terhadap penelitian yang sama (Noor,2011). Pengujian reliabilitas terhadap suatu variabel instrumen penelitian dikatakan reliabel jika memiliki nilai Cronbach Alpha> 0,60 .

3. Uji Asumsi Klasik

Untuk menguji apakah persamaan garis regresi yang diperoleh linier dan bisa dipergunakan untuk melakukan peramalan, maka harus Tabel 1 Hasil Uji Validitas dilakukan uji asumsi klasik yaitu Uji Normalitas

4. Analisis Regresi Linear Berganda Analisis regresi linear berganda yaitu untuk mengetahui hubungan antara variabel bebas (independent) dan variabel terikat (dependent). Dalam penelitian ini menguji bahwa ada tidaknya pengaruh faktor-faktor yang mempengaruhi keputusan pembelian di Warkop 89 Mamuju. Adapun rumus regresi linear berganda yang digunakan adalah sebagai berikut:

$$
\mathrm{Y}=\mathrm{a}+\mathrm{b} 1 \mathrm{X} 1+\mathrm{b} 2 \mathrm{X} 2+\mathrm{b} 3 \mathrm{X} 3+\mathrm{e}
$$

5. Uji Hipotesis

Pengujian hipotesis ini dapat dilakukan dengan menggunakan uji statistic yaitu Uji F (Uji Serempak), Uji T (Uji Parsial)

\section{HASIL PENELITIAN DAN PEMBAHASAN}

\section{Uji Validitas}

\begin{tabular}{|c|c|c|c|c|}
\hline No. & Item & Total Pearson Correlation & $\mathrm{r}_{\text {tabel }}$ & Keterangan \\
\hline 1 & $\mathrm{X} 1$ & 0,555 & 0,50 & Valid \\
\hline 2 & $\mathrm{X} 2$ & 0,732 & 0,50 & Valid \\
\hline 3 & $\mathrm{X} 3$ & 0,663 & 0,50 & Valid \\
\hline 4 & $\mathrm{Y}$ & 0,809 & 0,50 & Valid \\
\hline
\end{tabular}

Sumber : Data primer diolah, 2020

Dari tabel tersebut di atas menunjukkan bahwa semua variabel $\mathrm{X}$ baik $\mathrm{X}_{1}, \mathrm{X}_{2}$, dan $\mathrm{X}_{3}$ dinyakatan Valid karena nilai korelasi diatas 0,50 serta variabel Y juga memiliki nilai korelasi diatas 0,50 dinyatakan valid.

1. Uji Reliabilitas

Tabel 2 Hasil Uji Reliabilitas

\begin{tabular}{|c|c|c|c|l|}
\hline No. & Item & Cronbach's Alpha & Nilai standar & Keterangan \\
\hline 1 & $\mathrm{X} 1$ & 0.849 & 0,60 & Reliabilitas \\
\hline 2 & $\mathrm{X} 2$ & 0.921 & 0,60 & Reliabilitas \\
\hline 3 & $\mathrm{X} 3$ & 0,926 & 0,60 & Reliabilitas \\
\hline 4 & $\mathrm{Y}$ & 0,877 & 0,60 & Reliabilitas \\
\hline
\end{tabular}


Sumber : Data primer diolah, 2020

Berdasarkan uji reliabilitas di atas, dapat dikatakan bahwa seluruh item reliabel. Ini dapat dilihat dari keseluruhan item pertanyaan memiliki cronbach's alpha if item deleted di atas nilai cronbach alpha yaitu 0,60 . Sehingga dapat disimpulkan bahwa semua item-item pengukur variabel dari kuesioner adalah reliabel yang berarti bahwa kuesioner yang digunakan dalam penelitian ini merupakan kuesioner yang handal.

2. Analisis Regresi Linear Berganda

Analisis hasil penelitian mengenai pengaruh pengetahuan Tabel 3 Hasil Perhitungan Regresi konsumen terhadap keputusan nasabah memilih bank syariah, yang dianalisis dengan menggunakan metode kualitatif dan kuantitatif. Analisis kuantitatif digunakan untuk membuktikan hipotesis yang diajukan dengan menggunakan model analisis regresi linear berganda, sedangkan analisis kualitatif digunakan untuk menelaah pembuktian analisis kuantitatif

Adapun hasil olahan data dengan menggunakan program SPSS 20 (Statistical Package for Social Science 20) dapat dirangkum melalui tabel berikut ini :

Coefficients $^{\mathrm{a}}$

\begin{tabular}{|c|c|c|c|c|c|}
\hline \multirow{2}{*}{ Model } & \multicolumn{2}{|c|}{ Unstandardized Coefficients } & Standardized Coefficients & \multirow{2}{*}{$\mathrm{t}$} & \multirow{2}{*}{ Sig. } \\
\hline & $\mathrm{B}$ & Std. Error & Beta & & \\
\hline (Constant) & -1.83 & 0.85 & & -2.153 & 0.034 \\
\hline $\mathrm{X} 1$ & 0.195 & 0.057 & 0.280 & 3.409 & 0.001 \\
\hline $\mathrm{X} 2$ & 0.125 & 0.042 & 0.157 & 2.939 & 0.004 \\
\hline $\mathrm{X} 3$ & 0.405 & 0.049 & 0.599 & 8.192 & 0.001 \\
\hline
\end{tabular}

Sumber: Output SPSS 20, 2020

Berdasarkan hasil olahan data regresi dengan menggunakan program komputerisasi SPSS versi 20, maka dapat disajikan persamaan regresi yaitu sebagai berikut :

$$
\begin{aligned}
\mathrm{Y}= & \mathrm{a}+\mathrm{b} 1 \mathrm{X} 1+\mathrm{b} 2 \mathrm{X} 2+\mathrm{b} 3 \mathrm{X} 3+\mathrm{e} \\
\mathrm{Y}= & -1,830+0,195 \mathrm{X} 1+0,125 \mathrm{X} 2 \\
& +0,405 \mathrm{X} 3+\mathrm{e}
\end{aligned}
$$

Dari persamaan regresi tersebut di atas, maka dapat diberikan penjelasan sebagai berikut :

bo $=-1.830$ merupakan nilai konstanta, yang diartikan bahwa jika Kualitas produk, kualitas pelayanan, dan lingkungan konstan maka nilai keputusan konsumen melakukan kunjungan terhadap Warkop 89 mengalami penurunan kunjungan sebesar 1,830 satuan

$\mathrm{b}_{1} \mathrm{X}_{1}=0,195$ yang memberikan arti bahwa Kualitas produk berpengaruh positif terhadap keputusan konsumen melakukan kunjungan terhadap Warkop 89. Hal ini menunjukkan bahwa dengan setiap penambahan 1 satuan tanggapan responden mengenai Kualitas produk maka akan memengaruhi keputusan konsumen melakukan kunjungan terhadap Warkop 89 yakni sebesar 0.195 satuan.

$\mathrm{b}_{2} \mathrm{X}_{2}=0,125$ yang memberikan arti bahwa kualitas pelayanan berpengaruh positif terhadap keputusan konsumen melakukan kunjungan terhadap Warkop 89. Hal ini menunjukkan bahwa setiap penambahan 1 satuan tanggapan responden mengenai kualitas pelayanan maka akan keputusan konsumen melakukan kunjungan terhadap Warkop 89 yakni sebesar 0,125 satuan.

$\mathrm{b}_{3} \mathrm{X}_{3}=0,405$ yang memberikan arti bahwa lingkungan pendukung berpengaruh positif terhadap keputusan konsumen melakukan kunjungan terhadap Warkop 89. Hal ini menunjukkan bahwa setiap penambahan 1 satuan tanggapan responden mengenai lingkungan maka akan memengaruhi keputusan konsumen melakukan kunjungan terhadap Warkop 89 yakni sebesar 


\section{0,405 satuan.}

Berdasarkan hasil persamaan regresi di atas maka dapat diketahui bahwa variabel bebas yang paling berpengaruh terhadap keputusan kunjungan konsumen terhadap Warkop 89 adalah variabel lingkungan, hal ini dapat dilihat melalui hasil koefisien regresi yakni sebesar 0,405 yang menunjukkan nilai koefisien regresi yang terbesar jika dibandingkan dengan nilai koefisien regresi dari variabel lainnya.

\section{Uji Parsial (Uji t)}

Uji $t$ dilakukan untuk mengetahui pengaruh masing-masing atau secara parsial variabel independen (Kualitas produk, kualitas pelayanan dan lingkungan) terhadap variabel dependen (keputusan konsumen melakukan kunjungan terhadap Warkop 89). Sementara itu secara parsial pengaruh dari ketiga variabel independen tersebut dapat dilihat pada tabel berikut ini

Tabel 4 Hasil Perhitungan Uji t

\begin{tabular}{|l|l|l|l|}
\hline Model & t-hitung & t-tabel & Sig. \\
\hline Kualitas Produk (X1) & 3,409 & 1,984 & 0,001 \\
\hline Kualitas Pelayanan (X2) & 2,939 & 1,984 & 0,004 \\
\hline Lingkungan (X3) & 8,192 & 1,984 & 0,001 \\
\hline
\end{tabular}

Sumber: Output SPSS 20, 2020

Pengaruh dari masing-masing variabel Kualitas produk, kualitas pelayanan dan lingkungan pendukung terhadap keputusan konsumen melakukan kunjungan terhadap Warkop 89 dapat dilihat dari arah tanda dan tingkat signifikan (probabilitas). Jika tingkat signifikansinya $<0,05$ dan t-hitung lebih besar dari t-tabel maka dapat dikatakan bahwa variabel tersebut berpengaruh dan signifikan.Hal ini dapat diuraikan sebagai berikut :

a. Pengaruh Kualitas produk terhadap keputusan konsumen melakukan kunjungan terhadap Warkop 89.

Hasil pengujian parsial (uji t) antara variabel Kualitas produk terhadap variabel keputusan konsumen melakukan kunjungan terhadap Warkop 89 menunjukkan nilai thitung sebesar 3,409 > ttabel 1,984 serta memiliki nilai probabilitas sebesar 0,001 yang lebih kecil dari 0,05, hal ini berarti bahwa Kualitas produk berpengaruh secara signifikan terhadap keputusan konsumen melakukan kunjungan terhadap Warkop 89. Berdasarkan data di atas dapat disimpulkan bahwa secara parsial variabel Kualitas produk (X1) dapat menerangkan variabel terikatnya yaitu keputusan konsumen melakukan kunjungan terhadap Warkop 89.

b. Pengaruh kualitas pelayanan terhadap keputusan konsumen melakukan kunjungan terhadap Warkop 89.

Hasil pengujian parsial (uji t) antara variabel kualitas pelayanan terhadap keputusan konsumen melakukan kunjungan terhadap Warkop 89 menunjukkan nilai thitung 2,939 > ttabel 1,984 serta memiliki nilai probabilitasnya sebesar 0,004 yang lebih kecil dari 0,05, hal ini berarti bahwa kualitas pelayanan (X2) berpengaruh positif dan signifikan terhadap keputusan konsumen melakukan kunjungan terhadap Warkop 89. Berdasarkan data di atas dapat disimpulkan bahwa secara parsial variabel kualitas pelayanan (X2) dapat menerangkan 
variabel terikatnya yaitu keputusan konsumen melakukan kunjungan terhadap Warkop 89.

c. Pengaruh lingkungan pendukung terhadap keputusan konsumen melakukan kunjungan terhadap Warkop 89.

Hasil pengujian parsial (uji t) antara variabel lingkungan pendukung terhadap variabel keputusan konsumen melakukan kunjungan terhadap Warkop 89 menunjukkan nilai thitung $8,192>$ ttabel 1,984 serta memiliki nilai probabilitas sebesar 0,001 yang lebih kecil dari 0,05, hal ini berarti bahwa lingkungan pendukung (X3) berpengaruh positif dan signifikan Tabel 5Hasil Perhitungan Uji F terhadap keputusan konsumen melakukan kunjungan terhadap Warkop 89. Berdasarkan data di atas dapat disimpulkan bahwa secara parsial variabel lingkungan pendukung (X3) dapat menerangkan variabel terikatnya yaitu keputusan konsumen melakukan kunjungan terhadap Warkop 89.

\section{Uji Simultan (Uji F)}

Uji statistik $F$ pada dasarnya menunjukkan apakah semua variabel independen yang dimasukkan dalam model mempunyai pengaruh secara bersama-sama terhadap variabel dependennya. Hasil perhitungan Uji F dapat dilihat pada tabel berikut ini :

\begin{tabular}{|c|c|c|c|c|c|l|}
\hline \multicolumn{2}{|c|}{ Model } & Sum of Squares & df & Mean Square & F & Sig. \\
\hline \multirow{3}{*}{1} & Regression & 517.84 & 3 & 172.61 & 137.63 & $.000 \mathrm{~b}$ \\
\cline { 2 - 7 } & Residual & 120.4 & 96 & 1.254 & & \\
\cline { 2 - 7 } & Total & 638.24 & 99 & & & \\
\hline
\end{tabular}

Sumber: Output SPSS 20, 2020

Dari hasil analisis regresi dapat diketahui bahwa secara bersama-sama variabel independen memiliki pengaruh yang signifikan terhadap variable dependen. Hal ini dibuktikan dari nilai Fhitung sebesar $137.628>$ Ftabel 2,699 dengan nilai signifikansi (sig) sebesar 0,000. Karena nilai signifikansi (sig) jauh lebih kecil dari 0,05 maka model regresi dapat digunakan untuk memprediksi keputusan konsumen melakukan kunjungan terhadap Warkop 89 atau dapat dikatakan bahwa Kualitas produk, kualitas pelayanan dan lingkungan pendukung secara bersama-sama (simultan) berpengaruh terhadap keputusan konsumen melakukan kunjungan terhadap Warkop 89.
Pembahasan dalam penelitian menguraikan pengaruh pengaruh Kualitas terhadap keputusan konsumen melakukan kunjungan terhadap Warkop 89. Dimana Kualitas produk meliputi : cita rasa produk, harga produk, penampilan menu, keragaman produk dan kustomisasi produk terhadap keputusan konsumen melakukan kunjungan terhadap Warkop 89.

1. Pengaruh Kualitas produk terhadap keputusan konsumen melakukan kunjungan terhadap Warkop 89. Dari hasil persamaan regresi diperoleh nilai koefisien regresi untuk Kualitas produk sebesar 0,195 , selain itu memiliki nilai thitung $=3,408>$ t-tabel $=1,984$, serta memiliki nilai pvalue $=0,001$ 
$<0,05$, sehingga dapat dikatakan bahwa Kualitas produk mempunyai pengaruh secara signifikan terhadap keputusan konsumen melakukan kunjungan terhadap Warkop 89.

2. Pengaruh kualitas pelayanan terhadap keputusan konsumen melakukan kunjungan terhadap Warkop 89

Dari hasil perhitungan regresi, maka diperoleh koefisien regresi untuk kualitas pelayanan sebesar 0,125 , selain itu memiliki thitung 2,939> ttabel 1,984 dan memiliki nilai pvalue $0,004<0,05$, sehingga dapat disimpulkan bahwa kualitas pelayanan mempunyai pengaruh yang signifikan terhadap keputusan konsumen melakukan kunjungan terhadap Warkop 89 dan dapat diketahui pula bahwa variabel bebas yang paling berpengaruh terhadap keputusan konsumen melakukan kunjungan terhadap Warkop 89 adalah variabel kualitas pelayanan.

3. Pengaruh lingkungan pendukung terhadap keputusan konsumen melakukan kunjungan terhadap Warkop 89

Hasil perhitungan koefisien regresi diperoleh nilai untuk variabel lingkungan pendukung sebesar 0,405, selain itu memiliki nilai thitung 8,192 > ttabel 1,984 serta memiliki nilai pvalue $0,001<0,05$, dengan demikian dapat dikatakan bahwa terdapat pengaruh yang signifikan antara lingkungan pendukung terhadap keputusan konsumen melakukan kunjungan terhadap Warkop 89.

\section{KESIMPULAN}

Dari rumusan masalah yang diajukan, analisis data yang telah dilakukan dan pembahasan yang telah dikemukakan pada bab sebelumnya, maka dapat ditarik beberapa kesimpulan sebagai berikut :
1. Berdasarkan hasil pengujian regresi linear berganda maka dapat disimpulkan bahwa variabel kualitas produk (X1) sebesar 0,195, kualitas pelayanan (X2) sebesar 0,125 dan lingkungan eksternal pendukung (X3) sebesar 0,405 mempunyai pengaruh positif dan signifikan terhadap keputusan konsumen melakukan kunjungan terhadap Warkop 89. Sehingga hipotesis pertama yang mengatakan bahwa diduga atribut produk, kualitas pelayanan dan lingkungan eksternal pendukung mempunyai pengaruh yang positif terhadap keputusan konsumen melakukan kunjungan terhadap Warkop 89 dapat diterima.

2. Berdasarkan hasil pengujian regresi maka dapat diketahui bahwa variabel yang paling besar pengaruhnya terhadap keputusan konsumen melakukan kunjungan terhadap Warkop 89 adalah variabel lingkungan pendukung (X3) karena memiliki nilai koefisien regresi yang terbesar serta memiliki nilai probabilitas yang terkecil dari variabel lainnya. Dari hasil pengujian secara parsial (uji T), hasil penelitian membuktikan bahwa masing-masing variabel independen berpengaruh positif dan signifikan terhadap variabel dependen karena memiliki thitung yang lebih besar dari ttabel dan memiliki tingkat signifikan (probabilitas) lebih kecil dari 0,05. Dan secara simultan (uji F), hasil penelitian membuktikan bahwa variabel independen (kualitas produk (X1) sebesar 3,409, kualitas pelayanan (X2) sebesar 2,939 dan lingkungan pendukung (X3) sebesar 8,192 secara simultan mempunyai pengaruh yang signifikan terhadap keputusan konsumen melakukan kunjungan terhadap Warkop 89. 


\section{Saran}

Berdasarkan kesimpulan yang diperoleh dalam penelitian ini, maka diajukan saran sebagai pelengkap terhadap hasil penelitian yang dapat diberikan sebagai berikut :

1. Bagi peneliti selanjutnya, diharapkan dapat meneliti konsumen secara keseluruhan yaitu konsumen ataupun bukan konsumen dari Warkop 89 sehingga memperoleh hasil yang lebih variatif dan akurat mengenai faktorfaktor yang berpengaruh terhadap keputusan konsumen untuk mengunjungi Warkop 89.

2. Disarankan agar perusahaan mampu meningkatkan kualitas produk, kualitas pelayanan dan kenyamanan lingkungan sekitar khususnya bagi pelanggan potensial Warkop 89.

\section{DAFTAR PUSTAKA}

Aaker, D. A. dan G.S. Day. 2016. Marketing Research: Private and Public Sector Decisions. John Wiley \& Son Inc. New York.

Anik. 2012. Kebutuhan Dasar Manusia: Aplikasi. Konsep dan proses. Jakarta: Salemba Medika

Buttle, Francis. 2015. Customer Relationship Management Concepts and Technologies, Stan Maklan. Routledge.

Damajani R.R Dhian, 2008. Vernakularisme, Informalitas, urbanisme; Cafe sebagai Ekspresi Gaya Hidup Kontemporer. ITB J. Vis. Art \& Des. Bandung

Engel, J. F., R. D. Blackwell dan P. W. Miniard. 2010. Perilaku Konsumen. (Terjemahan, Jilid 1). Binarupa Aksara, Jakarta. Giant Taman Yasmin Bogor.

Hosmer, D \& S. Lameshow. 2013. Applied Categorical Data
Analysis. Jhon Wiley and Sons. New York.

Kotler P. 2011. Manajemen Pemasaran. Jilid 1,2. Jakarta(ID): Indeks Kelompok Gramedia.

Kotler P, Keller KL. 2012. Marketing Management. $14^{\text {th }}$ ed. New Jersey. Pearson Prestice Hall.

Kotler, Philip, dan Keller, Kevin Lane. 2016. Manajemen Pemasaran, Edisi 15. Alih Bahasa: Benyamin Molan. PT Prenhallindo. Jakarta.

Listyari. 2016. Analisis Keputusan Pembelian dan Kepuasan Konsumen Coffee Shop De Koffie Pot. Skripsi. Program Studi Manajemen Agribisnis. Fakultas Pertanian . Institut Pertanian Bogor. Bogor.

Nazir, M. 2003. Metode Penelitian. PT Ghalia Indonesia. Jakarta.

Perreault, William D., Cannon, Joseph P., \& McCarthy, E Jerome. (2016). Basic Marketing. 19th. ed. New York: McGraw-Hill.

Rama, Fanny. 2010. Analisis Sikap Dan Faktor-Faktor Yang Mempengaruhi Keputusan Kunjungan Konsumen Kafe Baca Di Buku Kafe, Depok Jawa Barat. Skripsi. Program Studi Manajemen Agribisnis. Fakultas Pertanian . Institut Pertanian Bogor. Bogor.

Tjiptono Fandy, Ph.D, 2014. Pemasaran Jasa, Andi, Yogyakarta

Swasta, Basu dan T. Hani Handoko. 2012. Manajemen Pemasaran: Analisis Perilaku Konsumen. Liberty. Yogyakarta. 